\title{
JUAN GELMAN EN LA HISTORIA DE LA POESÍA HISPANOAMERICANA RECIENTE: NEORROMANTICISMO Y NEOEXPRESIONISMO
}

\author{
POR \\ Miguel GoMes \\ The University of Connecticut-Storrs
}

\section{EN LAS FRONTERAS DEL CANON}

La obra del argentino Juan Gelman cuenta ya con seguidores en diversos países hispanos y figura en prestigiosas compilaciones colectivas. ${ }^{1}$ En torno a ella se ha consolidado también el interés de lectores especializados, que queda corroborado por la publicación incluso de antologías críticas como la organizada por Lilián Uribe hacia 1993. El hecho de que, sin embargo, ensayistas y antólogos ampliamente conocidos decidan, no menos, pasar por alto la labor gelmaniana ${ }^{2}$ nos habla de la naturaleza profundamente perturbadora y polémica de ésta. Dicha índole contradictoria nos permite entrever en esta escritura un elemento determinante a la hora de entender la coyuntura estética hispanoamericana de fines del siglo XX y está enmarcada en ciertos problemas de historia literaria a los que me gustaría remitirme en estas páginas.

Un par de críticos ha situado a Gelman en un momento clave de la poesía de la región: el de la ruptura con un canon ya casi conformado en el decenio de 1950, en el que Pablo Neruda, por una parte, y Octavio Paz, por otra, desempeñaban papeles protagónicos. Hugo Achugar es el primero de esos estudiosos y a él debemos la descripción más completa de un desencuentro de opiniones acerca del oficio poético:

Gelman, pero también Nicanor Parra, Ernesto Cardenal [...] y otros muchos comenzaban a apostar a una lírica de lo cotidiano, de lo claro, de lo sentimental, [...] de lo social. Apuesta anacrónica para los [Hugo] Friedrich de América Latina que pretendían ignorar la poesía de Brecht como parte de la historia moderna. Apuesta que disputaba la hegemonía nerudiana de una lírica exuberante y rechazaba en Canto general y en Odas elementales

\footnotetext{
' Entre otras: Pedro Lastra y Luis Eyzaguirre, Catorce poetas hispanoamericanos de hoy en Inti 189 (1984) Número especial; Jorge Rodríguez Padrón, Antología de poesía hispanoamericana (19151980), Madrid: Espasa-Calpe, 1984; Julio Ortega, Antología de la poesía hispanoamericana actual, México: Siglo XXI, 1987; y, en griego, Rigas Kappatos, Dieciséis poetas latinoamericanos, Atenas: A. Carabia, 1980.

${ }^{2}$ El caso más notorio es el de la extensa pero injustificadamente abarcadora Antología de la poesía hispanoamericana moderna coordinada por Guillermo Sucre (2 vols. Caracas: Monte Ávila, 1993). Por otra parte, La máscara, la transparencia, verdadera obra maestra de la crítica continental, que junto a los clásicos comenta a poetas obscuros, soslaya asimismo a Gelman.
} 
lo que la retórica debía a su dicción anterior. Apuesta que rechazaba la poesía social de los treinta y de los cuarenta en lo que de explícito o cartilla tenían; apuesta que encumbraba tanto al Vallejo de Poemas humanos y de España, aparta de míeste cáliz como al de Trilce" (Uribe, Como temblor 27).

Achugar, poco después, llama la atención también a la considerable diferencia entre la empresa gelmaniana y la "solipsista" que Octavio Paz - y, con él, Guillermo Sucreproponía como solución para los excesos épicos de Neruda; Paz y Sucre, en el fondo, siguen regidos por principios de raigambre simbolista, según los cuales la solidaridad emotiva con otros seres humanos resulta postergable como factor literario (29). A los juicios de Achugar se sumarán los de María-Rosa Olivera Williams, que añade la sugerencia de que la obra de Gelman, Parra, Cardenal y otros coetáneos en gran medida "responde a una mentalidad 'posmodernista', con el sentido que dicho término posee en inglés" (Uribe, Como temblor 174). Si se olvida el anglicismo desorientador, cuya función en la historiografía literaria hispánica cumple desde muy temprano la palabra "postvanguardia", el parecer de Olivera Williams es justo y sumamente productivo, pues alude al carácter ambiguo de la relación entre Gelman y las poéticas dominantes que lo antecedieron: el "post" no afirma ni oposición ni desvinculación absolutas, sino una actitud crítica con respecto a gustos e inclinaciones previas. Aunque se intenta abolir el atronador americanismo nerudiano, se verifica una continuidad de su ideal filantrópico; aunque se abandone el hermetismo de otros vanguardistas, la pasión por el experimento lingüístico típico de éstos se perpetúa, fundida, eso sí, con códigos populares - la imaginería del tango, por ejemplo. Gelman, en la visión tanto de Achugar como de Olivera Williams, sirve de claro paradigma de las búsquedas aún no totalmente perfiladas ni canceladas que originó la entronización de las vanguardias de la primera mitad del siglo.

Ahora bien, creo necesario ahondar todavía más en algunos vislumbres que aparecen en los trabajos críticos mencionados, pues tal exploración permitirá definir con precisión mayor tanto la herencia vanguardista gelmaniana como la transformación de ésta en signo de un código muy personal y poco afiliable a anacrónicas supervivencias estéticas.

La primera pieza en nuestro proceso de reconstrucción de una poética será considerar la pertinencia de la mención a Bertolt Brecht que figura en la cita de Achugar. Luego, pasaremos a examinar las consecuencias que tiene la afinidad de Gelman con ciertos planteamientos de la vanguardia germánica en el contexto específico de las letras hispanoamericanas de fines del siglo XX. Intentaremos comprender, de esta manera, cómo la originalidad de la escritura gelmaniana se vincula a la proposición de una imago mundi a tono tanto con circunstancias sociales como con un diálogo con la tradición literaria.

\section{II. "NeORROMANTICISMO" Y "NEOEXPRESIONISMO": UNA SENSIBILIDAD BRECHTIANA}

El vocablo "neorromanticismo", con el cual Achugar caracterizaba en su artículo la orientación general de la obra de Gelman (30), ofrece problemas en español, pues la pobreza de dicho movimiento en las literaturas ibéricas - pobreza que pocas excepciones compensan - ha llevado con frecuencia a una reducción que, trasladada al ámbito internacional, no podría de ninguna manera justificarse. La reducción a la que me refiero 
transforma el término "romántico" ya sea en mero "egocentrismo", ya sea en "blanda melancolía". ${ }^{3}$ No se toma en cuenta, con todo, que tal óptica no sería aplicable a la enorme lista de creadores europeos y americanos que, precisamente impulsados por el romanticismo, llamaron la atención hacia el papel político y combativo del artista. El hecho de que el liberalismo haya sido la forma que, por circunstancias históricas, adoptó esa inclinación "comprometida" - piénsese en Hugo - no desmiente para nada la orientación social e incluso rebelde de dicho movimiento en sus mejores exponentes. Si nos limitáramos a Hispanoamérica, ¿qué mejor prueba que toda la poesía gauchesca o textos como $\mathrm{El}$ matadero para convencerse de que la "blandura" no puede erigirse en sinónimo de romanticismo? Por todo lo anterior, hemos de descartar en estas páginas dicho entendimiento de la palabra, obviamente explicable por los estereotipos a los que la coloquialidad suele confinar complejos fenómenos intelectuales.

Justamente, no considero descabellado asegurar que el acierto mayor de Achugar haya sido el hacernos ver el elemento romántico de la escritura de Gelman. Este supuesto requiere que nos detengamos en algunos pormenores. En un libro célebre, The Mirror and the Lamp, M.H. Abrams propuso hacia principios de los años cincuenta un par de metáforas críticas que resumían y sabiamente explicaban sin demasiados silogismos la historia de las poéticas antiguas y modernas hasta el siglo XIX. La concepción de la literatura como "espejo", que imperó durante milenios, hablaba de reproducciones y copias del universo; la concepción de la literatura como "lámpara" presentaba el quehacer creador como iluminación, intervención en el mundo, transformación de éste. El primero describía un arte pasivo, que complació, por ejemplo, a los neoclásicos; el segundo, uno activo, tal como lo exigieron los románticos. El siglo XX es heredero de ambas posturas y puede percibirse en sus autores y movimientos distintas variaciones, sutiles o ambiguas a veces, de la tradición.

La elegida por Gelman resulta en gran medida neorromántica por engendrar un discurso cuya postura ante el entorno es marcadamente subjetiva. A eso se refieren los críticos cuando, como Achugar, mencionan en esta poesía "valoración del sentimentalismo", "ternura celebrada sin hipocresías" (Uribe, Como temblor 32), o, como prefiere Mario Benedetti, "delirio" (55); es decir, fuerzas provenientes de una interioridad que se introducen en las configuraciones de lo real que nos ofrecen los poemas. Si toda escritura es equiparable al acto de fundar un espacio verbal imaginario, no nos queda más remedio que describir esta obra como creación desde dentro, a partir de elementos no presentes previamente en el entorno referencial sino traídos a él luego de un acto introspectivo por parte del sujeto textual. El romanticismo, como es bien sabido, intentó abrir la compuerta de lo irracional, del pathos, en su intento de desarticular los poderes de la conciencia: nada más revolucionario estéticamente en su momento y nada más caracterizable como bien adquirido por la posteridad -renovado, por cierto, sin cesar. Shelley, en $A$ Defense of Poetry (1821-40), definía por ello a la poesía como "the expression of imagination y connate with the origin of man". Teniendo en cuenta esas proposiciones románticas tan influyentes, también como "expresionista" y "humanista" sería analizable la poética de Gelman.

¿Por qué expresionista? No sólo porque la manifestación de la interioridad haya sido objetivo central romántico, sino porque el movimiento expresionista que está en las raíces

\footnotetext{
${ }^{3}$ Opinión que recoge, por ejemplo, Mario Benedetti a la hora de referirse a Gelman (Uribe, Como temblor 41).
} 
de la vanguardia del siglo XX jamás ocultó su deuda con el Sturm und Drang y fue, en algunos aspectos, resurrección e intensificación de éste (Poggioli 228). Y ya que hemos visto la posibilidad "transhistórica" de calificar de neorromántica la obra de Gelman, contemplemos ahora la alternativa histórica e intertextual de hacer exactamente lo mismo. Achugar recordaba a Bertolt Brecht a la hora de reflexionar sobre el poeta argentino: nada más oportuno, pues aquel escritor, formado durante el período de mayor vigencia expresionista de la vanguardia, ${ }^{4}$ ha sido mencionado por Gelman a la hora de reflexionar acerca de un concepto que desciende directamente de la "ironía" que reconocieron los románticos alemanes: aquélla entendida como contemplación en la escritura de lo que creemos más familiar, el Yo, como entidad ajena, distante - lo que precipita la destrucción de toda mimesis o aristotelismo estético. A eso, pasado por el cedazo del formalismo ruso, llamaba Brecht "efecto de alienación" (Verfremdung). Gelman readopta la tesis para hablar de su ocasional recurso a heterónimos:

Después de Gotán escribí nueve libros, unos dos mil poemas, antes de Traducciones III. El resto de esos nueve libros va a salir ahora [...]. Allí están Traducciones II (que es un japonés) y Traducciones I (que es un inglés). Efectivamente, cuando empecé con el inglés, fue para extrañarme de algo que me estaba ocurriendo (extrañarme lo digo en el sentido brechtiano), porque mi poesía se estaba volviendo muy íntima (Benedetti 228-9).

Las afinidades entre la sensibilidad de Brecht y la de Gelman son varias. Ambos, además de cultivar la lírica, escriben libretos de ópera y de cantatas. Por otra parte, los dos defienden un quehacer literario políticamente responsable, en sintonía con premisas socialistas. La convergencia estética, a mi modo de ver, es aun mayor si atendemos a que en uno y otro la deformación (acaso también regeneraciỏn) expresionista del universo tiene cabida. Comenzando por lo que algún crítico del joven Brecht ha denominado "retórica de la descomposición" (Demetz 2). Si la recordada "alienación" brechtiana no fuese un añadido suficiente a este argumento, para confirmar la validez de las afinidades propuestas podemos prestar atención al final de Mahagonny Songspiel donde se exclamaba: "la gente sueña con Mahagonny porque el mundo está descompuesto..." O a ciertas líneas anteriores de la familia Peachum en Die Driegroschenoper: "así que eso es todo. / El mundo está miserable y el hombre es una mierda" ...; o de Watzmann en Baal: "¿Qué es la carne? La carne es algo que se pudre como el espíritu". Estas pocas palabras sintetizan una cosmovisión compartida por muchos creadores germánicos entre 1910 y 1930 que Brecht perpetuará - subrepticia - hasta en sus últimas obras, donde dominan la estilización o la representación paroxística, denunciadora, a veces grotesca, siempre trágica, de un orbe imbuido de cualidades anímicas, no mero retrato objetivo de cosas o seres.

Claro está, la convergencia de Brecht y Gelman no ha de limitarse a una relación de estímulo directo. Después de todo, el expresionismo caló, aunque pocas veces se note, profundamente en la Argentina, muy abierta a las novedades estéticas que llegaron de

\footnotetext{
${ }^{4}$ Pese a que durante una época la crítica stalinista -en colaboración con el autor mismo, desde luego- se esforzó en negar la huella del expresionismo en Brecht, ésta ha sido reivindicada convincentemente: "Fortunately for us, Brecht did continue to commit some of the sins of his Expressionist teachers" afirma, por ejemplo, Peter Demetz (5).
} 
Europa durante la primera mitad del siglo XX. Borges, ya en 1920, publicaba traducciones de poetas pertenecientes al movimiento, con el cual se había familiarizado durante su estadía en Suiza; su metafísica del arrabal, tan pronunciada en sus primeros poemarios, tenía mucho en común con las humanizaciones o espiritualizaciones de lo inanimado frecuentes en la cultura alemana. $^{5}$ Jaime Giordano, por otra parte, ha reconocido en Roberto Arlt un exponente obvio de la estilística fracturante y desfiguradora de la vanguardia del norte y el centro de Europa (Edad 125-37). Y, en fin, hasta la fecha, el único estudio más o menos extenso acerca de la presencia del expresionismo en Hispanoamérica, que debemos a Naomi Lindstrom, está dedicado justamente a escritores rioplatenses: Literary Expressionism in Argentina.

En las próximas páginas creo conveniente que discutamos con detalle los ideologemas y rasgos discursivos que hacen más patente la inserción de Gelman en esa constante de las letras de su país.

\section{UN MUNDO DESCOMPUESTO.}

Nuestro ya mencionado Giordano, en otro trabajo, esta vez dedicado a los versos de Gelman, ha trazado el periplo de una voz lírica "de profunda sensibilidad y bizarro acercamiento a la palabra, que vive intensamente las etapas de descubrimiento del dolor, aparición de la rabia, presencia de la derrota, supervivencia [...] en imágenes de ausencia" (Dioses 274). El resultado de semejante itinerario, o su causa, quizá sea la creación o plasmación de una imago mundi muy particular. Ésta, en efecto, está signada por la descripción de una devastación general, una negación firme a concebir la existencia como orbe de triunfos o ascensos; dicha postura invita a otra: la dominada por la pesadumbre y la caída simbólica de la Psique en la vida individual y colectiva.

No por casualidad, se ha visto - pensemos en Achugar, entre otros críticos - gran similitud entre César Vallejo y el poeta que aquí nos ocupa. Viene al caso recordar que Robert Bly, en uno de los pasajes de su Iron John, ha propuesto la labor vallejiana como ilustración acuciosa del "camino de cenizas" de la depresión iniciática, en la que es natural captar al fin los lados sombríos de un Dios "enfermo" (72-84). Otro tanto sería justo aseverar de Gelman, quien en Velorio del solo (1961) incluía un "Arte poética" que ofrece lapidariamente, hacia el final, frases como: "nunca fui el dueño de mis cenizas, mis versos, / rostros oscuros los escriben como tirar contra la muerte" (24). Con todo, el tono desgarrado gelmaniano se caracteriza por la persistencia de una imaginería de descomposición - tomo la palabra de Brecht-y decaimiento en la cual lo mesiánico, al contrario de lo que ocurre con Vallejo, encuentra poco asidero.

Lilián Uribe, con ocasión de comentar el poemario Anunciaciones (publicado en 1988 pero escrito hacia 1985), ofrece una descripción que podría perfectamente hacerse extensible a buena parte de la obra de Gelman:

\footnotetext{
${ }^{5}$ En "Ginebra", texto borgiano incluido en Atlas (1984), leemos explícitamente: "De todas las ciudades del planeta [...] Ginebra me parece la más propicia a la felicidad. Le debo, a partir de 1914, la revelación del francés, de alemán, del expresionismo..."
} 
nos enfrentamos a una realidad degradada. Esa degradación se manifiesta, por un lado, a través de formas expresivas [...] que evidencian un proceso de deterioro: una llave sin puerta, un café vacío, espejos que ya no reflejan, musas cariadas, la pasión reventada, noticias desteñidas [...]. Con igual función desmitificadora advertimos la recurrencia al tono fuertemente irónico que acompaña los poemas y que parecería atacar esencialmente ciertas formas del poder: el canario autorizado por el comité central del parpadeo, calandrias filológicas, la paloma de la razón portátil [...]. De la mano de la ironía va la amargura" (Como temblor 112-3).

Como bien acota Uribe, la voz lírica en ese libro en particular adopta la actitud del superviviente, aquél que tiene la desazón de quien ha presenciado una verdadera guerra la Argentina, desde luego, estaba saliendo de un largo período de violencia interna cuyo nefasto corolario sería el enfrentamiento con Inglaterra por las Malvinas. Pero la "supervivencia" podría entenderse como el epílogo y la prolongación de un itinerario que determina las modulaciones del sujeto gelmaniano. En otras palabras, la imagen del mundo que hallamos en los últimos versos de Gelman, aunque decantada y acaso de mayor serenidad intelectual, sigue siendo básicamente la misma de sus libros previos: retomando metáforas de Giordano, podríamos decir que la amargura actual no es sino la "madurez" de la desesperación previa.

La desesperación a la que me refiero es semejante a la de los expresionistas: recordemos que ellos también experimentaron los horrores de la guerra con una intensidad innegable. No en vano la pintura de Munch presagiaba muchas de las inclinaciones del movimiento: el universo que representaban estaba impregnado de desequilibrio, tensión espiritual, cierta aspiración secreta hacia el caos, locura dionisíaca, angustia, dolor extremo - hasta los límites del patetismo, la fragmentación o la contorsión torturada de lo fenoménico (Torre 1: 187ss; Hirsch 54; Modern passim). Creo que la imaginería de la poesía de Gelman concuerda con un estado de ánimo expresionista porque suele ordenarse tácitamente gracias a dos fuerzas: una de destrucción y otra de reconstrucción. Por una parte, el enfrentamiento con una realidad que ha dejado de serlo, transformada en pesadilla, no ajena a lo "feísta" (Moraña 20-1); por otra, la necesidad de hallar en la solidaridad humana un remedio para una existencia cuyos valores se desmoronan hasta ir a dar a lo absurdo.

El primero de los procesos mencionados se hace obvio gracias a la reiteración obsesiva, de un poemario a otro, de la imagen de lo "roto", lo "desmembrado" o su variante más frecuente, la de los "pedazos" - acaso la palabra que mejor representa la exasperación del pathos gelmaniano. Aquí y allá, dichas figuraciones, a fin de perfilar en un lento mosaico una existencia destrozada, nos remiten a distintos aspectos de lo cotidiano.

En el principio, es decir, Violín y otras cuestiones (1956), el primer libro de Gelman, lo que se resquebraja está en la dicción poética misma; la descomposición o desarticulación que después se proyectará sobre el mundo proviene de la literatura y la tirantez ética que su cultivo, para un individuo interesado en asuntos prácticos, "reales", supone; así pues, leeremos en "Oficio":

Cuando al entrar al verso me disloco o no cabe un adverbio y se me quiebra toda la música, la forma mira 
con su monstruoso rostro de abortado, me duele el aire, sufro el sustantivo, pienso qué bueno andar bajo los árboles o ser picapedrero o ser gorrión y preocuparse por el nido [...], quién me manda pelear con la gramática, maldecirme de noche, rechinar fieramente, negarme, renegar, gemir, llorar, qué bueno está el gorrión [...] o ser picapedrero, óigame amigo, cambio sueños y músicas y versos por una pica, pala y carretilla.

Con una condición:

déjeme un poco

de este maldito gozo de cantar.

Años más tarde, en Gotán (1962), si bien en el poema del mismo título ya encontramos una aplicación distinta de la metáfora - la cuarta estrofa habla de "furia" y "tristeza" cayendo "a pedazos"-, el discurso metalingüístico todavía se impondrá y veremos cómo lo emotivo sigue siendo un escenario que la reflexión acerca del oficio ocupa. El título de uno de los textos, "En la carpeta", por ejemplo, evidencia la naturaleza impostergablemente semiótica del asunto sentimental aludido:

Tomé mi amor que asombraba por los astros y le dije: señor amor, usted crece de tarde, noche y día [...], sus ruidos no me dejan dormir perdí todo apetito y ella ni nos saluda, es inútil, inútil.

De modo que tomé a mi amor, le corté un brazo, un pie, sus adminículos, hice un mazo de naipes $\mathrm{y}$ ante la palidez de los planetas me lo jugué una noche lentamente mientras mi corazón silbaba, el distraído.

En Cólera Buey (1965) el ludismo afable se perderá y la tropología que se cristaliza en torno al despedazamiento se tiñe de mayor violencia. En el poema "Argelia", percibiremos que el foco de atención se desplaza a lo político:

ah dueños de la cólera del miedo y la venganza [...]

ah pueblos bellos solos la noche es larga y dura ahora tiene el aroma de mujeres húmedas mujeres cortadas a pedazos en Argelia la dura sus pedazos violentos duran como paredes donde duran las frases del odio y la ternura argelia tiene huesos podridos bajo tierra que crecerán en huesos podridos todavía 
húmedo de mujeres y pedazos violentos

que a lo mejor perdonan algún día algún día ...

Y ese malestar, causado por las injusticias políticas, no sólo raya en lo escatológico y paroxístico, sino que se extiende ahora al quehacer creador, que no se impone a los demás asuntos, sino que es medido con la misma regla por una voz poética deseosa de equilibrar los términos de la dicotomía "mundo" (en este caso, las facetas prácticas de la experiencia) y "belleza" (la escritura, el "verso" del que se nos hablaba en Violín y otras cuestiones):

estos poemas, esta colección de papeles esta

CCLXI

manada de pedazos que pretenden respirar todavía

estas palabras suaves ásperas ayuntadas por mí

me van a costar la salvación [...]

más malas que el dolor son estas

ruinas que levanté viviendo dejando de vivir

andando entre dos aguas

entre este mundo y su belleza ...

La inversión del giro idiomático "costar la perdición" retrata con exactitud la difícil armonía lograda.

Dicha paz, sin embargo, será temporal. En Los poemas de Sidney West (1969), homenaje a la Spoon River Anthology de Edgar Lee Masters - pero mucho más, ciertamente, pues encaja a la perfección en la evolución del pensamiento poético de Gelman-, volveremos a toparnos con imágenes de fragmentación teñidas por un desasosiego y un pesar mucho más intensos de lo que permitirían entrever los títulos de los poemas, entre elegíacos e irónicos. Así, el "Lamento por los pies de carmichael o'shaughnessy", donde una "indefinida desgracia" se cierne sobre las cosas, y el amor mismo viene "mal y triste y destrozado", presenta al personaje como víctima mucho menos evanescente que las argelinas de Cólera Buey, de una descomposición monstruosa:

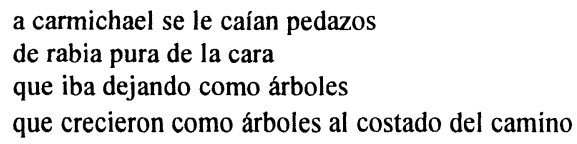

Pero tal desintegración del ser humano, detalle importante, borra los límites entre él y el espacio, haciendo mucho más aguda la destrucción de las formas que la sola mención de "pedazos". Igual consecuencia tendrán otros pasajes, como aquél del "Lamento por el sicomoro de tommy derk" donde literalmente el cuerpo humano se ha convertido en leña y ha de desmembrarse, obvia transposición del mitema de la destrucción dionisíaca:

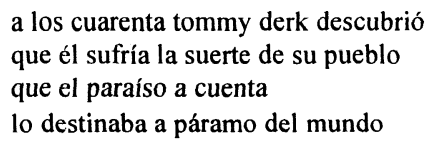




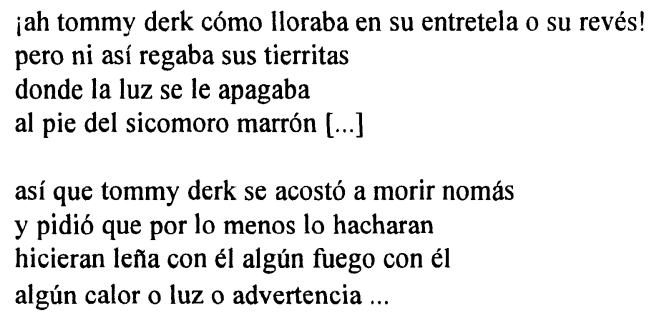

Por supuesto, la manifestación más rotunda de la descomposición o pérdida de forma del universo en esta serie de textos no será tanto el empleo explícito de tales metáforas como el juego enunciativo mediante el cual el hablante adopta máscaras para variar los "efectos de alienación" brechtianos: antes y después de Sidney West ha habido diversas "traducciones" y coautorías en la poesía de Gelman, en la que el "otro" puede ser ficticio o no (Uribe "Juan Gelman" 5). No sería desacertado admitir, por lo tanto, que la persistencia de dicha otredad enfática constituye una sutil transformación de la tropología desintegradora en planos fenomenológicos más determinantes en los que se hace posible cuestionar la unidad del "Yo" lírico de un modo casi tan eficiente como en el caso de Pessoa - por algo, en una pieza de Hacia el sur (1982), Gelman rendirá emocionado tributo al poeta portugués que "tenía cuatro poetas adentro" y no ganaba para alimentarlos. No obstante, sería engañoso atribuir un cerebralismo excesivo como el pessoano a un escritor que, según hemos verificado, sugiere la necesidad de balance entre "mundo" y "belleza". Así pues, hemos de remitirnos nuevamente a los indicios de referencialidad inscritos en sus versos, que durante el decenio de 1970 y principios de siguiente se volverá un elemento mucho más crucial.

La violencia que conmocionó a la Argentina durante esos años afectará muy de cerca a Gelman, pues, como es bien sabido, cobró entre sus víctimas al hijo del poeta y a su nuera encinta (Benedetti en Uribe, Como temblor 50). Ese triste dato "exterior" - además de muchos otros: el exilio, la tortura y persecución de otros allegados-no dejará de hacer acto de presencia en el "interior" del texto y es en el seno de tal duplicidad fenomenológica donde la imaginería de lo fragmentario encuentra un significado profundo y sincero. Notas (1981) contiene el poema más estremecedor, en que la congoja no sólo "rompe" las cosas, sino la sintaxis misma, obstruida y percusora, como la que corresponde a un hablante aniquilado por el sufrimiento:

\section{NOTA I}

te nombraré veces y veces.

me acostaré con vos noche y día.

noches y días con vos.

me ensuciaré cogiendo con tu sombra.

te pisaré loco de furia.

te mataré los pedacitos.

te mataré una con paco.

otro lo mato con rodolfo.

con haroldo te mato un pedacito más.

te mataré con mi hijo en la mano. 


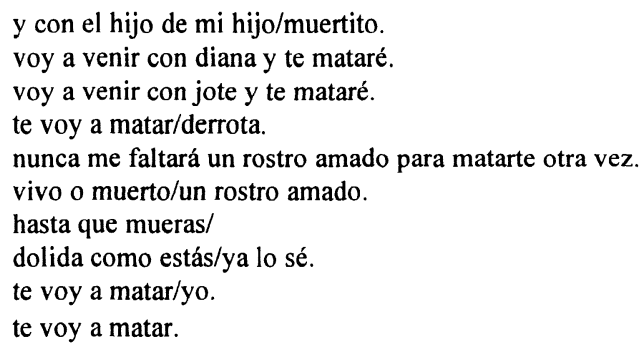

El expresionismo de Gelman, por una parte, supera toda racionalización, ya que carece de explicación evidente o directa y es "patológico", no por ser enfermizo, sino por responder a un sujeto lírico empeñado en conmocionar, en manifestarse menos a través de la dignidad del ethos que a través de los afectos y las pasiones. Ésta es, a mi modo de ver, la vía elegida en la totalidad de su poesía. No hay en ella indicio de que el padecimiento nos haga mejores o nos santifique mediante la voluntad; no hay el "cáliz" redentor vallejiano. Queda a nuestra disposición, entonces, una voz entregada completamente al trance casi místico de la consubstanciación con su lenguaje de penuria; una resignación unívoca a no esperar nada más allá de la sola formulación verbal de un modo de existir. Es ésta la variante más extremada de una estética expresionista: exteriorización no de una idea o un sentimiento específicos, sino de la urgencia misma de hacerlo. Si lo que hubo al principio era la aflicción, al final sólo persiste el abandono a un movimiento, que no es sino repetición interminable. Tal trayectoria se plasma magistralmente, para citar un solo caso, en otro poema del Notas:

\section{NOTA V}

no echés a la tristeza del fogón/

siéntese aquí a mi lado/vieja/

usté nunca me va a dejar/

perdonemé si la olvidé

si anduve de rabia en rabia saliendo de un muerto entrando en otro muerto o mundo roto/

si así viajé en todos estos años/

arrímese/tristeza/que

me hace frío tanta furia

$y$ tanto puerto muerto $y$

necesito viajar/viajar

El "mundo roto" es identificable, por supuesto, con la "realidad degradada" de la que hablaba Lilián Uribe y con el "mundo descompuesto" de Brecht. Con todo, si seguimos prestando atención, podremos percatarnos de otros detalles significativos. Por ejemplo, la aliteración "puerto muerto" no es inocente: la vaguedad del alucinado "viajar/viajar" concuerda con la inexistencia de un lugar que dé dirección y sentido a la vida. Por eso, en 
la poesía de Gelman nos enfrentamos con expresión en bruto, expresión pura y no solamente comunicación utilitaria: el lenguaje que ha producido el dolor transcurre, es, no podríamos intercambiarlo por acciones - algo siempre ha de restarnos del "maldito gozo de cantar". Constituye el verdadero y único puerto en el que, paradójicamente, nos desplazamos. Y no creo superfluo hablar de paradojas cuando Gelman es autor de un libro como Citas y comentarios (1982), en el que pone su palabra en intercambio dialógico, entre otras, con las de Santa Teresa y San Juan de la Cruz.

Muchas otras variaciones y síntomas de la cosmovisión "rota" nos ofrecerá esta poesía y sus ramificaciones imaginales son diversas. En el ámbito elocutivo - hemos tenido ya oportunidad de advertirlo someramente - la sintaxis suele reforzar la fractura constatada en el enunciado; pero no sólo la sintaxis: también el recurso gráfico a barras diagonales, cuya acción prosifica, aliena externamente al verso; las enumeraciones caóticas; la eliminación de la puntuación y de las mayúsculas; la desemantización de ciertas palabras; los solecismos y barbarismos de toda especie, en particular los neologismos. El resultado es una "intensificación" lingüística, como ha señalado Yoel Mesa Falcón en un lúcido artículo donde se estudia exhaustivamente el estilo gelmaniano (Uribe 83-107). De hecho, el exacerbamiento expresivo del poeta no consiste únicamente en un retrato atormentado del mundo que acaba encarnándose en el sujeto lírico. Creo que el cuidado con que reflexionemos en el lenguaje de sus textos podrá completar más eficientemente nuestra perspectiva. Lilián Uribe ha destacado la creación, a partir de "arcaísmos, neologismos, cambios de género, sustantivos en función de verbos, adjetivos con características adverbiales", de un "contralenguaje de resistencia" que sirve para hablar de la realidad degradada ("Juan Gelman" 6-7). La sugerencia es pertinente y nos ayuda a entender por qué en una pieza como "Pars poética" (perteneciente a Cólera buey) el hablante modelado por Gelman rinde cuentas de su estilo sin disociarlo de su versión del universo:

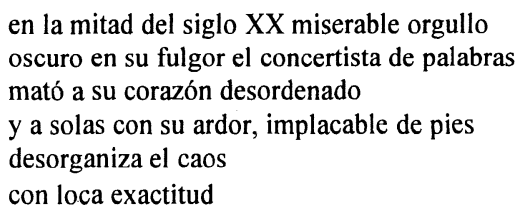

Hay caos sumo, como parecen indicar las líneas anteriores, no sólo en las referencias, sino en los medios con que se efectúan las operaciones referenciales. El texto, por lo tanto, ha de entenderse como afín al cosmos doliente y no como substancia privilegiada, ajena a él. No olvidemos la equiparación de "versos" y "cenizas" hecha en el Velorio del solo. A lo que voy, sin embargo, es a que tenemos que estar prevenidos contra la ilusión auspiciada por muchos poemas - o cuentos, novelas, dramas - de que el mundo "exterior" explica el "interior" de la escritura; tal ilusión tiene como propósito hacer más eficaz el artificio literario, no fijar un orden fenomenológico de la creación artística que como lectores discretos hemos de aceptar. Si sufrimos o comulgamos en el padecimiento humano leyendo a Gelman, no es porque hayamos experimentado lo que podemos intuir que el hombre que escribe ha podido experimentar, sino porque la literatura misma nos hace participar de sus 
experiencias en potencia, captables por toda persona con un mínimo de cultura letrada y de comprensión, en este caso, del español. No importa que en la intimidad el individuo que se aproxima a la literatura sea feliz o triste, optimista o pesimista. El lenguaje o la inteligencia lingüística del texto, desde sus entrañas, proyecta una imagen de la existencia que nosotros trasladamos a la página o percibimos en ella. Me atrevería a decir que por ese motivo las menciones directas, nominales, de los causantes del dolor en los versos de Gelman suelen postergarse, recurriéndose así a la última provisión de recato del hablante herido y transido de pesar. Lo que cuenta es la expresión, la verbalización del horror y el sufrimiento; lejos estamos de una ingenua acusación en forma de obra literaria. Un poema, ya se sabe, no puede poner preso a un dictador ni a un torturador - y mucho menos en el prosaico e injusto siglo XX -; pero la necesidad del hablante de expresarse es ciega y a ella se entrega. "Confianzas", pieza perteneciente a Relaciones (1973), ya lo había insinuado, con la magistral inversión de conceptos y estructura en la que se hacen contrastar la primera y la última estrofa:

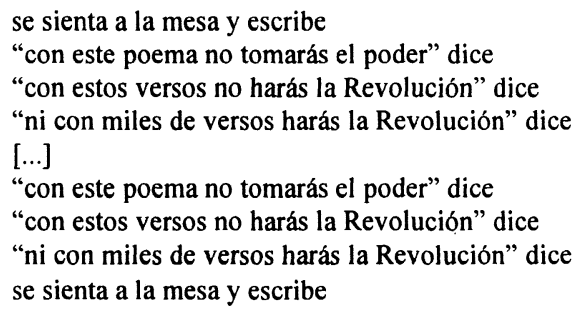

Cuando Gelman opta por la entronización del lenguaje rinde homenaje a innumerables escritores hispanoamericanos modernos. Observaba Pedro Henríquez Ureña hacia 1927 que una de las fuentes más poderosas de inquietud ontológica en el continente es la lengua: "No hemos renunciado a escribir en español, y nuestro problema de expresión original y propia comienza ahí. Cada idioma es una cristalización de modos de pensar y sentir. Nuestra expresión necesitará doble vigor para imponer su tonalidad sobre el rojo y el gualda" (21). Esta última alusión a la bandera española, obviamente, intentaba retratar como netamente emancipadora la cuestión de la posesión de la lengua. La violencia, los rigores a los que somete Gelman el léxico y la sintaxis del español normativo son parecidos a los puestos en práctica por la vanguardia, pero es también afiliable, en el siglo XIX y en el campo de la prosa, a los experimentos pictórico-ensayísticos de Simón Rodríguez y a la cólera ortográfica de Manuel González Prada, para sólo nombrar dos casos memorables. Sea como sea, me parece evidente que el rasgo más innegablemente personal de la escritura de Gelman es la vinculación estrechísima de sus palabras desorganizadas, caóticas, locas a la configuración de un universo sólo en apariencia "exterior", pues ha sido hecho a la medida del lenguaje, espacio donde una esperanza dolida, pero fervorosa, se refugia.

\section{RENACIMIENTO ENTRE CENIZAS}

Ahora bien, no todo es escatología en esta obra. Las afinidades entre su poética y la del expresionismo germánico es tan honda que también verificaremos, además del deterioro, 
otro proceso que afecta a su imagen del mundo; páginas atrás lo habíamos denominado "reconstrucción". En Los poemas de Sidney West, junto a los desmembramientos, la descomposición y la destrucción de seres y cosas, encontramos, de hecho, una respuesta alentadora que salía de la confusión de víctimas humanas de la violencia con la vegetación y el resto del espacio natural; en esa vida orgánica, desde luego, las resurrecciones y regeneraciones son posibles. Nadie mejor que Edgar O'Hara en un artículo sobre Sidney West ha visto "la aventura subterránea de los cuerpos y su añorada reconstitución. Por allí respiran, dándose otro origen, reconociéndose en la perseverancia de una piel de significados que pujará hasta hacerse de visible carne" (Uribe, Como temblor 167). Pero no sólo al mencionado poemario y a su peculiar repertorio de imágenes se limita la corriente constructiva de la obra de Gelman. Indisociable de las metáforas de lo fragmentario hallaremos una veta opuesta en la que los pedazos se juntan, las formas se recomponen, lo dividido se reúne. Ello, desde por lo menos los años setenta, cuando el tono desesperado se hacía más evidente en los libros del poeta y encontramos alusiones a los amigos y a los parientes desaparecidos:

[Emilio] quería que no se sueñe más [...]

y cada hombre se cosiera ya dulcemente sus mitades...

(“Muerte de Emilio Jáuregui” en Fábulas, 1971)

en tu boca/sol mío/pueda ver/ entender tu admirable companía/ ayudame a juntar todas mis almas/

("Cita XLII [santa teresa]" en Citas y comentarios)

....ंqué otro/

de mí/debiera ser/

para saber ver/los pedazos

de mundo que en silencio juntás?...

(“La lejanía" [eliezer ben jonon] en Com/posiciones, 1986)

Lo cierto es que la labor de reintegración se centra en la comunión con el otro. Tal postura es la que en este trabajo, a partir de palabras de Shelley, hemos llamado previamente "humanista", y la que Hugo Achugar ha denominado "neohumanista" (Uribe, Como temblor 30). Ninguno de estos términos se refiere, claro está, a un sermón acerca del ser humano como medida del universo; se trata más bien de una reinvención del hombre como empecinamiento, como permanencia, obstinado superviviente a todas las demoliciones y escatologías; e, incluso, terco transgresor de sus circunstancias personales, de la soledad que supone una identidad lograda por oposición a la de los demás. Por algo, Jaime Giordano ha titulado su ya citado artículo "Juan Gelman o el dolor de los otros".

Decía líneas atrás que ese gesto amoroso y social era tan expresionista como la representación de las ruinas, la locura, el apocalipsis y la decadencia del orbe. Creo que una breve ojeada a lo hecho por poetas germánicos de principios de siglo bastará para probarlo. Der Weltfreund ("El amigo del mundo") fue el primer título de Franz Werfel, quien publicó textos como el siguiente: 
Mi solo deseo, Hombre, es ser pariente tuyo.

Ya seas negro o acróbata o reposes todavía en el seno [maternal [...], ya seas soldado o aviador de coraje extremo yo te pertenezco a ti y a todo hombre.

Te lo suplico, hermano, no me resistas.

¡Ah, si pudiera ser que cayésemos uno en brazos del otro!

(Torre 1: 200)

No menos solidaridad se percibe en "La batalla del Marne" de Wilhelm Klemm, cuyos sentimientos de fraternidad humana no se borraron con la primera Guerra Mundial:

Lentamente la tierra comienza a moverse y a hablar [...].

Mi corazón es grande como Alemania y Francia juntas.

Está agujereado por las balas del mundo entero...

(Torre 1: 201)

En Gelman y en ellos la vivencia del horror no puede separarse de un renacer de la ternura. ${ }^{6}$

V. SUPERVIVENCIA DEL VANGUARDISMO COMPROMETIDO; ABOLICIÓN DEL VANGUARDISMO TELÚRICO Y ORATORIO

Después del examen que hemos efectuado no me parece inoportuno regresar al contraste inicial entre Gelman y el Neruda de Canto general. La diferencia entre el decir torturado y agónico del uno y el triunfalismo desbordante del otro es más que patente. Lo mismo podría señalarse con respecto a la propensión fragmentaria de uno - tanto en el plano de la cosmovisión como en la ambigua otredad enunciativa - y la tendencia a la monumentalidad sistemática, orgánica, general, del otro - nótese de paso que la fraternidad nerudiana se distingue de la de Gelman porque, en el fondo, disimula una voraz ampliación del "Yo", como la que sugiere el poema "A mi partido", penúltimo del Canto: "me has hecho indestructible porque contigo no termino en mí mismo".?

Si en Neruda encontramos una de las cimas del canon de la primera mitad del siglo en Hispanoamérica, sobre todo porque su obra conjuga las dos facetas más usuales de la literatura continental de entonces —el influjo de la vanguardia cosmopolita y la inspiración americanista, no podemos sino ver en Gelman un ejemplo pertinente de distanciamiento con respecto a ese horizonte. Y no sólo porque al mundonovismo rimbombante anteponga la derrota, la resignación y una simpatía humana menos estentórea, sino porque lo hace sin rechazos absolutos de lo que constituía un bien ganado de la tradición literaria ya entronizada: se prescinde de ciertos aspectos del Canto, pero no de todos ellos pues, a fin de cuentas, el compromiso con la historia se mantiene.

\footnotetext{
' La antología en español más penetrantemente comentada de la poesía expresionista alemana sigue siendo hoy la de Rodolfo Modern, publicada en Buenos Aires en 1950. A ella remito al lector.

${ }^{7}$ Más sobre este asunto y las dimensiones épicas o míticas del libro de Neruda puede hallarse en "El problema del hablante poético en el Canto general" de Nelson Osorio (Lévy-Loveluck 171-83) y "Orfeo en utopía: el poeta y la colectividad en Canto general" de Jean Franco (269-89).
} 
Vanguardista en cierta forma, Gelman aún echa mano de elementos con los que el expresionismo y en gran medida Vallejo se identificaron. Pero al hacerlo rompe con un canon que ellos no conocieron. Nada más apto que la ambivalente palabra "postvanguardia" para caracterizar esta obra.

El neoexpresionismo de Juan Gelman no consiste, únicamente, en su notoria tendencia a adentrarse en los dominios de la angustia; tampoco en su denuncia de los males sociales, políticos o morales contemporáneos. La necesidad de decir es lo que queda: la puesta en escena de la expresión desnuda, privilegio que sólo puede darse tras una comprensión honda de lo humano. La toma de partido en una contienda ideológica o material es importantísima en esta obra, pero, por depender de las circunstancias, no sabremos por el momento si lo más perdurable. Lo que no resultará tan fácilmente perecedero o datable, en cambio, es el "ardor" de esta poesía; su "loca exactitud".

\section{Obras cITADAs}

Abrams, M. H. The Mirror and the Lamp. Romantic Theory and the Critical Tradition. New York: Oxford University Press, 1953.

Benedetti, Mario. "Juan Gelman y la ardua empresa de matar la melancolía". Los poetas comunicantes. México: Editorial Marcha, 1971.

Bly, Robert. Iron John. A Book about Men. Reading: Addison-Wesley Publishing Company, 1990.

Demetz, Peter, ed. Brecht: A Collection of Critical Essays. Englewood Cliffs, NJ: Prentice-Hall, 1962.

Gelman, Juan. Antología poética 1956-1989. Selección, prólogo y bibliografía de Lilian Uribe. Montevideo: Vintén Editor, 1993.

Giordano, Jaime. Dioses, antidioses ... Ensayos críticos sobre poesia hispanoamericana. Concepción, Chile: Lar, 1987.

La edad de la náusea (sobre narrativa hispanoamericana contemporánea). Santiago de Chile: Instituto Profesional del Pacífico, 1985.

Henríquez Ureña, Pedro. Seis ensayos en busca de nuestra expresión. Buenos AiresMadrid: Babel, 1927.

Hirsch, Foster. The Dark Side of the Screen. New York: Da Capo Press, 1981.

Lévy, Isaac y Juan Loveluck, eds. Simposio Pablo Neruda-Actas. New York: University of South Carolina/Las Américas, 1975.

Lindstrom, Naomi. Literary Expressionism in Argentina. Tempe: Arizona State University, 1977.

Modern, Rodolfo E. El expresionismo literario. 1950. Buenos Aires: Nova, 1965.

Moraña, Mabel. "Un ruido en la oreja". Diálogo con Juan Gelman. Brecha. Montevideo 30/8/1991: 20-1.

Poggioli, Renato. The Theory of the Avant-Garde. 1962. G. Fitzgerald, tr. Cambridge: Harvard University Press, 1968.

Torre, Guillermo de. Historia de las literaturas de vanguardia. 3 vols. Madrid: Guadarrama, 1974. 
Uribe, Lilián, ed. Como temblor del aire: la poesía de Juan Gelman. Ensayos críticos. Montevideo: Vintén Editor, 1995.

"Juan Gelman y su maldito gozo de cantar". Prólogo a Juan Gelman, Antología poética 1956-1989. Montevideo: Vintén Editor, 1993. 